\title{
PENGARUH LINGKUNGAN SOSIAL DAN KEADAAN EKONOMI KELUARGA TERHADAP KESEHATAN MENTAL REMAJA DI KELURAHAN AEK TAMPANG
}

\author{
REPLITA \\ Dosen Fakultas Dakwah dan Ilmu Komunikasi IAIN Padangsidimpuan \\ Email: replita@yahoo.co.id
}

\begin{abstract}
The social environment gives effects to teenagers in Aek Tampang District Padangsidimpuan. This is caused of the unstable of their mental condition because they had the relationship with their mates which didnot have good religous soul yet. Beside, it is also caused of economical side of the family; the poor condition of many families in that place made the parent didnot have capability to fulfill their teenagers' needs. It made them become agitate, and they are lazy to practice the religious that they have.
\end{abstract}

Keywords: social environment, economical side, mental condition, and teenagers.

\begin{abstract}
Abstrak
Lingkungan sosial banyak memberikan warna kepada remaja di Kelurahan Aek Tampang Kota Padangsidimpuan, hal ini dapat disebabkan oleh karena kondisi mental remaja sering tidak stabil, dimana para remaja di Kelurahan Aek tampang banyak bergaul dengan teman sebayanya yang belum memiliki jiwa beragama yang kuat. Selain dari pengaruh lingkungan, juga diakibatkan oleh pengaruh keadaan ekonomi keluarganya, dimana keadaan ekonomi keluarga di Kelurahan tersebut banyak yang miskin sehingga orang tua tidak mampu menyahuti keinginan anak remajanya untuk memenuhi kebutuhannya, yang mengakibatkan remaja menjadi nakal, dan akibatnya mereka banyak yang malas mengamalkan ajaran agama yang di milikinya.
\end{abstract}

Kata Kunci: Lingkungan Sosial, keadaan Ekonomi, Kesehatan Mental, dan Remaja

\section{PENDAHULUAN}

Lingkungan yang di hadapi oleh remaja dapat dilihat dari lingkungan keluarga dan lingkungan sekolah dan lingkungan sosial masyarakat. Dimana lingkungan yang pertama di jumpai oleh remaja adalah lingkungan yang ada disekelilingnya yakni lingkungan keluarganya dimana orangtua sebagai 
2 | TAZKIR: Jurnal Penelitian Ilmu-ilmu Sosial dan Keislaman

Vol.02 No. 2 Desember 2016

pendidik pertamanya. Jika orangtua dalam keluarga memberikan pendidikan agama sejak dini pada anak, maka ketika dia sudah mencapai usia remaja akan lebih kuat mental beragamanya. dimana jika orang tua mengarahkan lingkungan bergaul anaknya sejak kecil maka ketika menginjak usia remaja lebih pandai memilih teman sebayanya.. Demikian halnya dengan keadaan ekonomi keluarga, dimana keadaan ekonomi juga memiliki peran yang sangat penting yakni dapat membuat kesuksesan dalam mendidik anaknya, termasuk anak remajanya. Remaja yang mendapatkan pendidikan yang bagus dari orang tuanya maka akan lebih sedikit pengaruh lingkungan socialnya terhadap anak remajanya, demikian juga sebaliknya.

Lingkungan sosial merupakan lingkungan yang tidak dapat dipisahkan dalam kehdupan manusia, karena tanpa adanya dukungan dari lingkungan sekitar seseorang tidak bisa berkembang dengan baik. Dimana lingkungan sosial yang kurang baik akan mempengaruhi kesehatan mental beragama remaja. D. Soejono mengatakan bahwa penyebab utama dari kejahatan -kejahatan adalah unsur lingkungan pergaulan hidup ${ }^{1}$. Jadi apabila remaja bergaul dengan orang yang rajin beribadah dan memiliki akhlak yang baik, maka besar kemungkinan remaja tersebut akan memiliki kesehatan mental beragama yang baik pula, demikian juga sebaliknya jika teman bergaul remaja di lingkungannya kurang bagus maka kesehatan mental beragama remaja menunjukkan kurang bagus pula.

Keadaan ekonomi keluarga dapat juga mempengaruhi kesehatan mental beragama remaja, dalam arti apabila perekonomian keluarga tersebut baik, maka untuk mewujudkan kesehatan mental remaja dalam beragama lebih mudah tercapai, yakni dengan tersedianya nafkah yang dapat digunakan untuk meningkatkan kualitas beragamanya. Begitu juga keluarga yang keadaan ekonominya rendah maka banyak remaja yang nekad untuk berbuat jahat karena kebutuhan hidupnya tidak dapat dipenuhi. Apalagi masa remaja yang belum matang mental beragamanya, sehingga dengan minimnya keadaan ekonomi keluarga banyak remaja yang meninggalkan ajaran agamanya. D. Soejono mengatakan bahwa kemiskinan mendorong kepada factor kejahatan dan menjadi motif sebab struktur kapasitas menghasilkan konflik-konflik yang tak terhitung jumlahnya. Orang miskin biasanya terpengaruh kepada meminum alkohol².

${ }^{1}$ D. Soejono, Doktrin-Doktrin Kriminologi, (Bandung: Alumni, 1989), hlm. 216.

${ }^{2}$ Ibid, hlm. 83. 
Keluarga merupakan salah satu tempat bagi remaja untuk tumbuh dan berkembang, meskipun demikian waktu dan kesibukan para remaja lebih banyak menghabiskan waktunya di luar rumah, baik karena pergi sekolah maupun ketika remaja bergaul dengan teman sebaya di lingkungan tempat tinggalnya. Pada prinsipnya remaja di rumah tangga dapat berkonsultasi dengan orangtua sebagai teman curhat. Jadi rumah merupakan tempat tinggal yang aman dan bahagia bagi remaja. Relasi yang baik dengan orang tua, menjadikan remaja terkadang bertahan di rumah. Namun tak sedikit pula remaja yang harus berjuang untuk dapat mempertahankan keberadaannya di rumahnya.

Untuk mewujudkan kesehatan mental remaja tidak bisa terlepas dari peran serta keluarga dan masyarakat dalam membina mental remaja. Beberapa hal yang dapat dilakukan keluarga dan masyarakat dalam meningkatkan kesehatan mental remaja yaitu: 1). Orangtua harus menyediakan watu dan tenaga, 2). Kesediaan merumuskan kegiatan, 3). Mengadakan kerjasama dengan berbagai pihak terkait. Mengkonsultasikan masalah kesehatan mental remaja kepada orangtua yang sedang terjadi. 4). Keluarga ikut berpartisipasi dan merencanakan, melaksanakan, memonitor dan mengevaluasi kesehatan mental beragama anak remajanya.

Dalam perkembangan kehidupan seperti sekarang ini banyak orang tua yang sulit mendidik anak remajanya dalam keluarga, apalagi kondisi orangtua yang sibuk mencari nafkah di luar rumah; sehingga remaja juga mencari kesibukan di luar rumah dan asyik dengan teman sebayanya menceritakan masalah yang mereka hadapi. Padahal mereka juga tidak mendapatkan solusi dari masalah yang mereka alami, dan pada akhirnya mereka nekad untuk mencari solusi dengan cara mereka sendiri, bahkan sering mereka mengorbankan kerusakan mental beragamanya. Mereka akhirnya meninggalkan ajaran agama dan gemar berbuat jahat, mengkonsumsi narkoba, pelecehan seksual dan remaja juga sering mengabaikan pendidikan agama yang diberikan orangtuanya dalam keluarga. Hal ini tidak terlepas juga dari kurangnya pengawasan orangtua terhadap pergaulan anak remajanya yang bebas dengan lingkungan sosialnya. Remaja banyak yang lebih sibuk dengan meggunakan jejaring sosial dengan memanfaatkan jasa internet ke warung internet.

Di Kelurahan Aek Tampang banyak remaja yang terpengaruh dengan lingkungan sosial yang kurang menguntungkan yakni lingkungan remaja yang kurang berminat dengan kegiatan-kegiatan keagamaan, mereka lebih senang 
4 | TAZKIR: Jurnal Penelitian Ilmu-ilmu Sosial dan Keislaman

Vol.02 No. 2 Desember 2016

mengikuti kenakalan teman sebayanya yang ada di lingkungan tersebut. Kurang sehatnya mental remaja di Kelurahan Aek Tampang dapat juga disebabkan karena banyaknya keluarga miskin di Kelurahan Aek Tampang, dimana dari data Badan Pusat Statistik kota Padangsidimpuan tahun 2014 di dijelaskan bahwa kemiskinan yang paling parah untuk Kota Padangsidimpuan berada di lokasi Kelurahan Aek Tampang. Dengan banyaknya keluarga yang miskin membuat para orangtua kurang dapat memenuhi kebutuhan anaknya, dan mereka sibuk mencari nafkah.

Dari hasil studi pendahuluan yang dilaksanakan oleh penulis menunjukkan bahwa di Kelurahan Aek Tampang banyak sekali remaja yang kurang sehat mental beragamanya hal ini disebabkan karena remaja banyak yang terpengaruh dengan lingkungan sosialnya, dan akibat keadaan ekonomi keluarga yang rendah, sehingga orangtua sibuk mencari nafkah untuk memenuhi kebutuhan keluarganya, akibatnya remaja sering bergaul dengan teman sebayanya di lingkungan sekitarnya.

Adapun tujuan penelitian ini adalah 1) untuk mengetahui bagaimana gambaran lingkungan sosial di Kelurahan Aek Tampang Kota Padangsidimpuan; 2) untuk mengetahui bagaimana gambaran keadaan ekonomi keluarga Kelurahan Aek Tampang Kota Padangsidimpuan; 3) untuk mengatahui bagaimana pengaruh lingkungan sosial tehadap kesehatan mental di kelurahan Aek Tampang Kota Padangsidimpuan; and 4) untuk mengetahui bagaimana pengaruh keadaan ekonomi keluarga terhadap keehatan mental beragama remaja di Kelurahan Aek Tampang kota Padangsidimpuan.

\section{TINJAUAN PUSTAKA}

\section{Lingkungan Sosial}

Lingkungan sosial merupakan bagian yang tidak terpisahkan dan kehidupan manusia. Dengan demikian lingkungan sosial adalah masyarakat serta berbagai sistem norma yang terdapat di sekitar individu atau kelompok manusia yang mempengaruhi tingkah laku mereka dan interaksi di antara mereka ${ }^{3}$.

Faktor lingkungan bisa saja menjadi faktor penghambat dalam meningkatkan pendidikan agama remaja, karena lingkungan yang kondusif dan lingkungan yang agamis akan dapat memberikan pengaruh terhadap

${ }^{3}$ Tim Penyusun Kamus Bahasa Indnesia, Pusat Peminaan Bahasa, Depdiknas, Kamus 
pengalaman remaja terhadap ajaran agama. Lingkungan keluarga adalah merupakan lingkungan pendidikan yang pertama dan utama, karena di dalam lingkungan keluarga anak pertama sekali mendapatkan pendidikan dan bimbingan serta mendapatkan pembinaan.

Lingkungan sosial termasuk juga lingkungan keluarga, dimana keluarga merupakan satuan sosial yang paling sederhana dalam kehidupan manusia, anggota-anggotanya terdiri dari ayah, ibu dan anak-anak. Bagi anak, keluarga merupakan lingkungan pertama yang dikenalnya, dengan demikian kehidupan keluarga menjadi fase sosialisasi awal bagi pembentukan jiwa kegamaan anak. Karena keluarga dinilai sebagai faktor yang paling dominan dalam meletakkan dasar bagi perkembangan jiwa keagamaan4. Menurut Charles Schaefer ada tiga cara untuk merubah alan lingkungan yaitu dengan menambahkan sesuatu kepada alam sekitar yang ada, mengadakan pengurangan hal-hal yang dianggap baik, membenahi kembali keadaan-keadaan lingkungan ${ }^{5}$.

\section{Tugas dan Tanggung Jawab Orangtua}

Orangtua merupakan pendidik pertama bagi anaknya, dan orang yang bertangung jawab atas perkembangan anak atau pendidikan anak adalah orangtuanya, karena adanya pertalian darah secara langsung bertanggung jawab atas masa depan anak-anaknya. Menurut Hamdani dan Fuad Hasan bahwa orangtua disebut sebagai pendidik kodrat karena merupakan pendidik yang tetap, mulai dari awal sampai di akhir dimana orangtua yang menentukan pendidikan anak sesuai dengan harapan dan keinginannya. Oleh karena itu, orangtua yang menentukan berhasil atau tidaknya menuju masa depan anak hingga tercapainya suatu tujuan yang diharapkan. Apabila pendidikan orangtua itu baik maka akan mencerminkan perilaku yang baik. Namun karena pihak orangtua tidak mempunyai kemampuan, waktu dan sebagainya, maka mereka menyerahkan semua tanggung jawabnya kepada orang lain yang berkompeten untuk melaksanakan tugas mendidik ${ }^{6}$. Tingkah laku atau akhlak orangtua dan keluarga mempunyai pengaruh yang besar terhadap pembinaan mental anak. Suasana keluarga damai tanpa disadari akan berpengaruh besar terhadap anak.

${ }^{4}$ Syamsul Yusuf, Psikologi Belajar Agama; Persfektif Agama Islam, (Bandung: Pustaka Bani Quraisy, 2005), hlm. 2.

${ }^{5}$ Charles Schaefer, Bagaimana Cara yang Efektif Mendidik dan Mendisiplinkan Anak, (Jakarta: CV. Tulus Jaya, 1986), hlm. 34.

${ }^{6}$ Hamdani Ihsan daan Fuad Hasan, Filsafat Pendidikan Islam, (Bandung: Pustaka Setia, 1998) hlm. 93. 
6 | TAZKIR: Jurnal Penelitian Ilmu-ilmu Sosial dan Keislaman

Vol.02 No. 2 Desember 2016

Apabila tingkah laku atau akhlak yang dilihat anak itu mengandung nilai-nlai positif, maka anak akan terbawa kepada nilai-nilai positif dan sebaliknya jika tingkah laku orangtua dan keluarga mengandung nilai-nilai negatif, maka akan dapat membawa kepada hal-hal yang negatif. Jadi pola asuh orangtua dalam membentuk dan menjaga kesehatan mental beragama anak adalah segala usaha yang dilakukan orangtua yang direalisasikan terhadap perkembangan fisik dan fisikis anak, pembinaan lingkungan sosial, pemilihan sistem pendidikan, cara berkomunikasi anak dengan orangtua, keteladanan orangtua, pengawasan nilai moral yang merupakan dasar berprilau anak.

Tanggung jawab yang perlu dilaksanakan orangtua adalah:

1. Memelihara dan membesarkannya.

2. Melindungi menjamin kesehatannya, baik secara jasmaniah maupun rohaniah dari berbagai gangguan penyakit atau bahaya lingkungan yang dapat membahayakan dirinya.

3. Mendidiknya dengan berbagai ilmu pengetahuan dan keterampilan yang berguna bagi hidupnya.

4. Membahagiakan anak untuk dunia dan akhirat dengan memberika pendidikan agama dengan ketentuan Allah SWT sebagai tujuan akhir hidup muslim? .

Kesehatan mental tidak dapat dipisahkan dengan kesehatan fisik, sebab ketika seseorang mengalami sakit secara fisik, terkadang merusak mental dan jiwanya, begitu juga sebaliknya. Oleh karena itu kesehatan mental harus terus ditingkatkan dengan memberikan siraman-siraman rohani atau bina mental oleh orang tua.

Jadi dengan pemberian pendidikan agama dapat mewarnai perilaku dan kepribadian anak. Lingkungan keluarga atau lingkungan tempat tinggal dapat memberikan pengaruh besar terhadap kehidupan remaja.

Pada saat sekarang masalah penting yang dihadapi keluarga adalah seperti yang diungkapkan Zakiah Drajat yang mengatakan bahwa orang tua dan anak sangat sulit berkomunikasi pada zaman sekarang, terkadang anaknya tidak mau menceritakan masalah dirinya kepada orangtuanya, kadang-kadang kesulitan yang mereka hadapi ditutup-tutupi pada orangtua ${ }^{8}$.

${ }^{7}$ Schoib Hawari, Pola Asuh Orangtua, http.www.com, diakses 25-3-2015 pukul 20.00WIB.

${ }^{8}$ Zakiah Drajat, Remaja Harapan dan tantangan, ( Bandung, Remaja Rosdakarya, 1994), hlm. 21. 
Pendidikan masyarakat merupakan lingkungan sosial yang berpengaruh terhadap kesehatan mental remaja. Jika mayoritas masyarakat memiliki pendidikan agama yang baik, maka mental remaja yang berda di lingkungan tersebut akan baik.

Sikap atau perlakuan masyarakat yang kurang memberkan kedudukan yang jelas bagi remaja, dan seringkali mempertajam rasa konflik yang sebenarnya, karena msyarakat kurang menghargai atau kurang memberi status yang pasti bagi remaja, sehingga sering muncul remaja membentuk kelompok kelompok remaja yang sikap dan tindakannya banyak menggambarkan sikap yang menentang nilai-nilai yang dianut oleh masyarakat. Akibatnya remaja banyak yang kurang sehat mentalnya.

\section{Keadaan Ekonomi Keluarga}

Keadaan ekonomi keluarga merupakan hal yang penting dalam kehidupan mulai dari hal yang kecil sampai hal yang besar, mulai dari kehidupan anak sekolah sampai ke Perguruan tinggi. Kecukupan dan kekurangan ekonomi orang tua dapat mempengaruhi tercapai tidaknya pendidikan kesehatan mental anak. Pengaruh ekonomi yang kurang memadai dapat menyebabkan kurangnya kesempatan orangtua bersama-sama dengan anaknya, dan kurangnya perhatian orangtua terhadap pendidikan agama anak, karena orangtua selalu disibukkan dengan mata pencahariannya dan kekurangan penghasilan keluarga dapat menyebabkan gagalnya anak dalam melanjutkan cita-citanya.

Faktor ekonomi rumah tangga sangat mempengaruhi terhadap kehidupan sosial maupun mental anggota keluarga, termasuk di dalamnya remaja, dalam arti apabila perokonomian rumah tangga tersebut baik, maka dengan mudah untuk melakukan berbagai kegiatan dalam hidupnya, sehingga para orang tua berjuang untuk mencari nafkah, agar anak-anaknya memiliki mental yang sehat dan kuat. Hal ni dilakukan mengingat banyaknya masyarakat yang memiliki ekonomi lemah, sehingga anak-anaknya tidak dapat dibiayainya yang membuat anaknya nakal menjadi bandel dan melawan pada orang tua.

\section{Kesehatan Mental}

Istilah kesehatan mental diambil dari konsep mental hygiene, kata mental berasal dari bahasa Yunani yang berarti kejiwaan. Kata mental memiliki persamaan makna dengan kata psyche yang berasal dari bahasa Latin yang 
8 | TAZKIR: Jurnal Penelitian Ilmu-ilmu Sosial dan Keislaman

Vol. 02 No. 2 Desember 2016

berarti mental yang sehat atau kesehatan mental. Kesehatan mental adalah terhndarnya seseorang dari keluhan dan gangguan mental baik berupa neurosis maupun psikosis penyesuaian diri terhadap lingkungan sosial ${ }^{9}$.

Diantara masalah penting yang dihadapi orangtua dengan anak remajanya adalah kurangnya komunikasi dan sosialisasi dengan anak remaja. Terkadang remaja tidak mau menceritakan masalah dirinya kepada orangtuanya, bahkan kesulitan yang dihadapi remaja ditutupi kepada orangtua.

Fatturrochman mengutip pendapat Dies dimana remaja yang memiliki kesehatan mental adalah remaja yang mampu:

1. Mengembangkan kemampuan psikologi, emosi, ntelektualserta spiritual secara berkembang.

2. Memiliki inisiatif, mengembangkan dan memelihara relasi pertemananmutual yang saling memuaskan kedua belah pihak.

3. Mampu memanfaatkan dan mengelola diri saat tdak tidak ada orang lain.

4. Peka dan memiliki rasa empati dengan sekitar.

5. Bermain dan belajar secara seimbang.

6. Mengembangkan kepekaan terhadap kejadian yang salah dan baik.

7. Menyelesaikan permasalahan dan dapat memetik hikmahnya dari permasalahan yang dihadapi ${ }^{10}$.

Kesehatan mental dapat meghilangkan goncangan dan hambatan yang terjadi pada zaman modern ini, dan upaya yang dilakukan adalah dengan mengusahakan tercapainya kesehatan jasmani dan rohani yang dapat menyesuaikan diri terhadap orde sosial yang ada, dan tidak melarikan diri dan realitas hidup.

\section{METODE PENELITIAN}

Penelitian ini dilaksanakan di Kota Padangsidimpuan dengan lokasi di Kelurahan Aek Tampang. Waktu penelitian ini dilaksanakan mulai dari bulan Juli 2015 sampai Bulan Desember 2015. Dalam penelitian ini digunakan yaitu jenis penelitian Mixing yakni menggabungkan antara jenis penelitian kualitatif dengan metode analsis secara deskriptif dan jenis penelitian kuantitatif dengan menggunakan analisis statistik. Populasi dalam penelitian ini adalah seluruh keluarga yang beragama Islam yang memiliki remaja yang ada di lingkungan IX Kelurahan Aek Tampang yang berjumlah 39 orang. Penelitian ini disebut dengan penelitian populasi. Instrumen yang digunakan daam penelitian ini

${ }^{9}$ Zakiah Drajat, Kesehatan Mental, Jakarta: Kalam Mulia, 2001), hlm.10.

${ }^{10}$ Faturrochman, dkk, Psikolog Untuk Kesejahteraan Masyarakat, (Yogyakarta: Pustaka Pelajar, 2012), hlm. 3. 
adalah observasi, wawancara dan angket yakni angket langsung dan tertutup. Adapun bentuk angket yang digunakan adalah dengan menggunakan Skala Likert yakni dengan memakai tingkatan pilihan dengan pilihan berganda $(a, b, c)$ dengan alternative jawaban, apabila dijawab responden a, maka bobotnya 3 , dan b, bobotnya 2, sedangkan c bobotnya 1 . Wawancara, dalam penelitian ini wawancara yang dilaksanakan adalah secara terstruktur yang dilaksanakan adalah pada orangtua dan anak remaja di kelurahan Aek Tampang.

Observasi yang dilakukan kepada remaja dan orang tua yang menjadi sampel penulis. Untuk melihat bagaimana pengaruh antara lingkungan sosial terhadap kesehatan mental beragama remaja maka dilaksanakan dengan menggunakan alat uji korelasi product moment dan melihat pengaruh dilanjutkan dengan uji Regresi Linear Sederhana.

\section{HASIL PENELITIAN DAN PEMBAHASAN}

Dari penelitian yang dilakukan maka keadaan lingkungan sosial di Kelurahan Aek Tampang dapat dilihat dari beberapa indikator yakni: dari hasil wawancara yang dilakukan pada kepala lingkungan IX Kelurahan Aek Tampang pergaulan remaja yang nakal adalah golongan remaja yang putus sekolah baik di tingkat SD, SMP dan SMA. Mereka sering melakukan keresahan dalam masyarakat seperti menghisap ganja dan sabu-sabu, bahkan mereka juga sering melakukan pencurian ke rumah masyarakat di sekitarnya ${ }^{11}$.

\section{Perhatian Orangtua Terhadap Remaja}

Cara orang tua mendidik anak remajanya juga cukup bervariasi, yakni ada yang mendidik anak remajanya dengan kasih sayang dan lemah lembut, sehingga anaknya tumbuh menjadi remaja yang taat menjalankan ibadah, ada yang mendidiknya dengan cara yang keras dan disiplin, sehingga ketika anak remaja mereka menjadi penakut dan mudah tersinggung, dan ada juga orangtua mendidik anaknya sejak kecil membiarkan anaknya tidak memperoleh ilmu pengetahuan agama ketika anak tersebut menjadi remaja ${ }^{12}$. Kemudiaan orangtua di Lingkungan IX banyak yang lalai dalam mendidik anak remajanya, karena ketika orangtua di wawancarai banyak yang mengatakan bahwa anak remaja sudah dianggap dewasa maka mereka sudah dapat memikirkan sendiri tentang sikap dan perilakunya yang baik dan buruk, dan orangtua juga mengatakan

${ }^{11}$ Wawancara tangal 12 Oktober 2015.

${ }^{12}$ Observasi tanggal 17 Oktober 2015 
10 | TAZKIR: Jurnal Penelitian Ilmu-ilmu Sosial dan Keislaman

Vol.02 No. 2 Desember 2016

bahwa memberikan nafkah juga bukan merupakan tanggung jawabnya terhadap anak remaja,mereka sudah dianggap mampu menafkahi diri mereka ${ }^{13}$. Dengan pola pikir orangtua seperti ini anak remaja disatu sisi seolah-olah dibebaskan dengan pilihan sikap dan perilakunya sementara anak belum memiliki pembekalan ilmu yang mencukupi untuk hidup mandiri, akibatnya anak remaja mencoba menemukan jati dirinya di masyarakat dengan modal ilmu apa adanya. Hal ini menyebabkan banyak terdapat di Lingkungan IX Kelurahan Aek Tampang anak remajanya menjadi bandel dan membuat ketidaknyamanan di lingkungan tersebut, seperti menggemari narkoba yang menyebabkan banyak remaja yang ketergantungan, dan ketika mereka tidak mampu membelinya maka mereka nekad untuk mencari uang dengan jalan mencuri uang masyarakat yang ada di lingkungan tersebut. Selain itu mereka juga sering bermain dengan anak gadis dengan pergaulana bebas, baik dengan anak gadis yang ada di lingkungan tersebut maupun dengan anak gadis di luar lingkungan itu.

Dalam pengamatan lanjutan, orangtua hanya sedikit yang memberikan hukuman kepada anaknya dengan kenakalan tersebut, pada umumnya orangtua pasrah dan akibatnya orangtua tidak mampu lagi mengajari anaknya kearah yang lebih baik ${ }^{14}$.

Terjadinya pemikiran orangtua tentang cara mendidik anak remajanya yang agak keliru disebabkan oleh berbedanya tingkat pendidikan dan pengetahuan orang tua dalam mendidik anak remaja, dan juga disebabkan oleh sibuknya orangtua mencari nafkah.

Perhatian masyarakat terhadap pengawasan sikap dan perilaku remaja di lingkungan tersebut sangat rendah. Hal ini disebabkan karena masyarakat merasa bukan urusannya untuk memperhatikan anak orang lain. Menurut orangtua, remajalah yang bertanggungjawab dengan perangai anaknya, dan juga ada ketakutan masyarakat bahwa remaja tidak akan menerima nesehat yang diberikan mereka.

Dari pengamatan penulis menunjukkan bahwa sulitnya diatasi masalah kenakalan remaja di lingkungan ini akibat teman bergaul mereka yang kurang memiliki ilmu pengetahuan, sehingga mereka bergaul sesamanya tanpa ada yang mengajak kepada kebaikan. Mereka sama-sama suntuk (memiliki pikiran yang tidak karuan) dan sama-sama memiliki masa depan yang jelas, dan sama-

${ }^{13}$ Wawancara, Elfiannasari Ritinga, 17 )ktober 2015

${ }^{14}$ Observasi, 18 Oktober 2015. 
sama memiliki masalah yang tidak memiliki solusi akhirnya mereka secara bersama-sama nekad untuk merusak sikap dan perilakunya. Meskipun sekali seminggu pengajian wirid yasin ada dijadwalkan remaja, tetapi kehadiran mereka banyak yang bertujuan hanya ingin mencari pergaulan. Menurut penulis balum banyak perubahan sikap dan prilaku mereka dalam kehidupan seharihari. Hal ini penulis lihat bahwa selesai pengajian dilaksanakan maka para jemaahnya banyak berkeliaran dan mencari tempat-tempat aman untuk mengkonsumsi narkoba, dan pada waktu sholat banyak yang tidak melaksanakan sholat wajib lima waktu, baik di mesjid maupun di rumahnya. Hal ini dapat dibuktikan bahwa masih banyaknya remaja yang berkeliaran pada saat waktu sholat tiba, dan mereka merasa tidak berdosa ketika meninggalkan sholat, karena dari hasil wawancara menunjukkan bahwa remaja malas melaksanakan sholat karena pengetahuan mereka tentang agama sangat minim. Mereka juga mengatakan bahwa sejak kecil kurang dibiasakan orangtuanya mengajari anaknya di bidang agama utamanya ibadah sholat, dan ketika anaknya sudah remaja orangtuanya kurang terbiasa juga menyuruh anaknya sholat. Perilaku orangtua terhadap anak remajanya terjadi seperti ini menurut pengamatan penulis banyak orangtuanya sibuk mencari nafkah, juga karena orangtuanya kurang memiliki ilmu pengetahuan ${ }^{15}$.

\section{Keadaan Ekonomi Orangtua di Lingkungan IX Kelurahan Aek Tampang}

Di Lingkungan IX Kelurahan Aek Tampang termasuk Kelurahan yang paling miskin di Kota Padangsidimpuan, mata pencaharian masyarakatnya cukup bervsriasi yakni sebahasian kecil masyarakatnya yang PNS dan pedagang, dan mata penncaharian selainnya adalah buruh panggilan baik buruh rumahan maupun buruh lapangan, dan juga petani menyewa dan hanya sbagian kecil petani yang memiliki lahan sendiri. Untuk itu penghasilan orangtua di Lingkungan ini cukup bervariasi dan lebih banyak penghasilan yang tidak menetap jumlahnya per bulan. Dengan keadaan penghasilan yang tidak menetap maka orangtua banyak yang tidak mampu mensejahterakan anak remajanya, baik dari kesejahteraan pendidikannya, kesehatannya, pola makannya, dan kebutuhan lainnya, sementara kehidupan remaja menginginkan pola hidup yang serba ada, sehingga remaja pada umumnya menuntut kebutuhan yang banyak kepada orangtuanya. Dari hasil pengamatan penulis remaja yang banyak 
12 | TAZKIR: Jurnal Penelitian Ilmu-ilmu Sosial dan Keislaman

Vol.02 No. 2 Desember 2016

menuntut kebutuhan kepada orangtuanya dan ketika orangtuanya kurang mampu memenuhinya maka anak akan muncul sikap yang bermacam -macam seperti menangis, marah, benci dan akhirnya lari dari rumah. Dan remaja lingkkungan IX ini mencoba untuk mencari hidup sendiri dengan mengandalkan kemampuannya yang serba kekurangan, maka didapati remaja Lingkungan IX ini banyak yang menjadi Kornet mobil angkutan penumpang, dan setelah lama menjadi sopir mobil angkutan penumpang. Pencaharian lainnya remaja Lingkungan IX ini menjadi buruh panggilan yang tidak menetap. Dari pengamatan penulis remaja Lingkungan IX yang cepat mendapatkan pekerjaan menjadi putus sekolah dan mereka lebih sulit dididik orangtuanya, karena mereka merasa bahwa sudah mampu menghidupi diri sendiri dan mereka sudah bergaul di lapangan dengan berbagai karakter orang yang kurang terdidik. Kehidupan remaja yang seperti ini didominasi oleh remaja laki-laki, sedangkan remaja perempuan menjadi buruh rumahan seperti mencuci pakaian, mengasuh anak, menjadi pembantu rumah tangga ${ }^{16}$.

Dengan kondisi pendapatan seperti ini maka orangtua remaja sering mencari nafkah di luar lingkungannya, sehingga orangtua sering lama pulang ke rumah. Kondisi seperti ini membuat orangtua mudah marah, karena orangtua sudah kelelahan pada waktu siang hari.

\section{Kesehatan Mental Remaja}

Gambaran tentang kesehatan mental remaja di lingkungan IX Kelurahan Aek Tampang sangat banyak yang kurang sehat, dimana dari hasil observasi yang dilakukan oleh penulis menunjukkan bahwa anak remaja banyak yang tidak merasa tenang hidupnya, bahkan di rumahnya juga remaja kurang senang, sehingga mereka banyak yang mencari teman di luar rumah, bahkan jarang mereka tidur di rumahnya. Remaja tersebut banyak yang mangkal di tempattempat yang sunyi bersama dengan teman-temannya ${ }^{17}$.

Ketika penulis melakukan pendekatan kepada remaja di lingkungan IX Kelurahan Aek Tampang dan mengajak mereka untuk berbincang tentang perilaku beragama, maka remaja tersebut merasa malu dan takut dengan penelasn penulis. Remaja tersebut mengakui bahwa pelaksanaan ibadah sangat jarang dilakukan mereka. Bahkan ibadah yang mereka lakukan hanyalah ibadah sholat jumat saja dan sesekali jika bulan suci ramadhan maka mereka datang ke

\footnotetext{
16 Observasi, 30 Oktober, 2015.

${ }^{17}$ Observasi Tanggal 17 Oktober 2015.
} 
mesjid. Meskipun kelakuan remaja seperti ini, tetapi mereka merasa tidak ada kesalahan dan dosa ketika mereka tidak melaksanakan ibadah wajib, bahkan yang disalahkannya adalah orangtuanya dan orang yang baik-baik dilingkungannya, seperti pada teman-teman seusianya yang sudah berhasil cenderung mereka hindari karena mereka merasa rendah diri dan merasa iri hati.

Terjadinya kelakuan remaja seperti itu akibat mereka merasa tidak terbiasa mendapatkan pendidikan agama dari orang tuanya, sehingga mereka tidak terasah cara berfikirnya dan cara beribadahnya, akan tetapi menurut observasi yang dilakukan oleh penulis, dimana remajanya senang mengkonsumsi narkoba yang membuat remaja yang ad di lingkungan IX banyak yang stress ${ }^{18}$. Banyaknya remaja yang stress di lingknan tersebut membuat perilaku mereka kurang sopan pada orang lain.

\section{Pengujian Hipotesis}

Hipotesis yang diuji dalam penelitian ini adalah ada hubungan antara lingkungan sosial dengan kesehatan mental remaja di LingkunganIX Kelurahan Aek Tampang. Untuk menguji hipotesis penulis menggunakan rumus product moment. Dari data penulis memperoleh hasil perhitungan rxy 0,5685. Kemudian hasil perhitungan tersebut dikonsultasikan pada $r$ tabel dengan jumlah sampel 39 dan pada taraf signifikansi 5\%. Hasil $r$ tabel menunjukkan nilai sebesar 0,316 . Dari koefisien rxy dan nilai $r$ tabel, dimana $r x y=0,5685$ dan $r$ tabel $=0,316$ sehingga $\mathrm{rxy}>\mathrm{r}$ tabel, yaitu 0,5685 $>0,316$. Dengan demikian dapat dilihat bahwa hipotesis diterima. Kemudian untuk menguji msignifikansi hubungan antara dua variabel penulis melanjutkannya pada uji signifikansi dengan menggunakan rumus uji $\mathrm{T}$ yang memperoleh hasil perhitungan $\mathrm{t}$ hitung sebesar 4,20, kemudian untuk melihat kesignifikanan pengaruh antara lingkungan sosial dengan kesehatan mental remaja tersebut, maka $\mathrm{t}$ hitung dikonsultasikan pada tabel dengan tarif kesalahan $5 \%$ dan $d k=n-2$, yaitu $d k=39$ $2=37$. $\mathrm{t}$ tabel dengan taraf kesalahan $5 \% \mathrm{n}-2 \mathrm{dk}$ yaitu 39--2=37. Tabel untuk $\mathrm{dk}=$ 37 pada taraf signifikansi $5 \%$ tidak ditemuKan yang ada hanya pada $\mathrm{dk}=40$ dengan interpolasi diperoleh $\mathrm{t}$ tabel sebesar nilai 2,021, dan $\mathrm{dk}=37$ dengan nilai 2,042. Maka hasil untuk $\mathrm{dk}=37$ dapat dicari dengan menggunakan interpolasi. Dengan menggunakan interpolasidiperoleh nilai t tabel sebesar 2,0273, sehingga 
14 | TAZKIR: Jurnal Penelitian Ilmu-ilmu Sosial dan Keislaman

Vol. 02 No. 2 Desember 2016

diperoleh $\mathrm{t}$ hitung $>$ dari $\mathrm{t}$ tabel yaitu 4,20 > dari 2.0273 yang menyatakan pengaruh antara variabel $x$ terhadap y signifikan.

Dari beberapa uraian di atas rxy $>$ dari $\mathrm{r}$ tabel yaitu sebesar 0,5685 > 0,316 kemudian $\mathrm{t}$ hitung $>$ dari $\mathrm{t}$ tabel yaitu 4,20 > 2,0273 sehingga dapat dilihat ada pengaruh yang signifikan antara kondisi lingkungan sosial terhadap kesehatan mental remaja di lingkungan IX Kelurahan Aek Tampang.

Untuk meramalkan perubahan variabel y, jika variabel X1 diketahui, maka penulis melanjutkan pada uji regresi linear berganda dengan hasilnya menunjukkan harga $\mathrm{Y}$ ketika $\mathrm{X} 1=0$, dan angka atau koefisien regresi yang menunjukkan angka peningkatan ataupun penurunan variabel terikat yang didasarkan pada perubahan variabel bebas, jika (+) maka arah garis akan naik dan jika (-) maka arah garis akan turun.

Persamaan regresi linear bergandanya adalahm Y $=-17176947,5+$ 0,834X1 $+4,145 \mathrm{X}$. Jadi dari data di atas dapat dilhat bahwa hasil perhitungan b1 adalah 0,834 dan harga $r$ table adalah 0,316. Artinya hipotesis yang berbunyi terdapat pengaruh yang signifiakan antara variabel X1y dapat diterima, artinya Ho diterima dan ha ditolak. Dimana pegaruh antara lingkungan sosial ( X1), dengan kesehatan mental remaja ( Y) jcukup signifikan yakni sebesar 0,834. konstan adalah positif.atau setiap kenaikan lingkungan sosial satu satuan, maka kesehatan mental remaja akan meningkat sebesar 0,834 satuan. Artinya r data > dari $\mathrm{r}$ tabel yaitu sebesar 0,834 $>0,316$, sehingga dapat dilihat ada pengaruh yang signifikan antara kondisi lingkungan sosial terhadap kesehatan mental remaja di lingkungan IX Kelurahan Aek Tampang

Sedangkan untuk variabel $\mathrm{X} 2 \mathrm{Y}$ dapat dilihat bahwa hasil perhitungan $\mathrm{b} 2$ adalah 4,145 dan harga $r$ tabel adalah 2,0173. Artinya ${ }_{\text {rdata }}>$ dari $r$ tabel yaitu sebesar 4,145>2,0173. dengan demikian Ho dapat diterima dan Ja ditolak.

\section{PENUTUP}

Berdasarkan hasil penelitian dan pengujian hipotesis, maka dapat diambil kesimpulan sebagai berikut:

1. Kondisi lingkungan sosial di Kelurahan Aek Tampang menunjukkan bahwa dilihat dari keadaan adat istiadatnya cukup beragam, tapi masyarakatnya hidup dengan tenang dan tentram. Tapi dari segi pendidikan remaja banyak yang putus sekolah maka mereka banyak yang nakal dan mengikuti pergaulan bebas. 
2. Keadaan ekonomi keluarga di lingkungan IX menunjukkan bahwa ratarata ekonominya rendah, dimana orangtua remaja banyak yang pekerjannya menjadi buruh sembarangan, dan menjadi pengemud beca, serta menjadi petani, dan hanya sedikit orangtua remaja di lingkungan IX yang menjadi PNS. Rendahnya keadaan ekonomi keluarga mak membuat remaja banyak yang menjadi buruh atau kernet mobil angkutan umum. Akibat pekerjaan remaja yang berada di lapangan atau di luar rumah maka membuat pergaulan remaja menjadi bebas, yang mengakibatkan kurang sehatnya mental beragama remaja di Kelurahan Aek Tampang.

3. Pengaruh lingkungan sosial terhadap kesehatan mental renaja adalah dari data di atas dapat dilihat.

4. Ketika dilihat pengaruh antara variabel X1 terhadap y maka menunjukkan adanya pengaruh yang signifikan, dimana orangtua dan tokoh masyarakat yang kurang memberikan pendidikan agama dan pengawasan terhadap anak remaja maka mengakibatkan mental beragamanya kurang sehat. 
16 | TAZKIR: Jurnal Penelitian Ilmu-ilmu Sosial dan Keislaman

Vol.02 No. 2 Desember 2016

\section{DAFTAR RUJUKAN}

Abu Ahmadi, Ilmu Sosial Dasar, Jakarta: PT. Rineka Cipta, 1991 Ilmu Pendidikan, Jakarta: Rineka Cipta, 1991

Ana Ali Syahbana, M. Sidharta dan M.A.W. Brouwer, Menuju Kesejahteraan Jiwa, Jakarta: Gramedia, 1983

Andi Marpiare, Psikologi remaja, Surabaya: Usaha Nasional, 1983.

Charles Schaefer, Bagaimana Cara yang Efektif Mendidik dan Mendisiplinkan Anak, Jakarta: CV. Tulus Jaya, 1986.

D. Soejono, Doktrin- Doktrin Kriminologi, Bandung: Alumni, 1989

Elizabeth B. Hurlock. Psikologi Perkembangan , Jakarta: Erlangga,1985.

Faturrochman, dkk, Psikolog Untuk Kesejahteraan Masyarakat, Yogyakarta: Pustaka Pelajar, 2012

Hasan Langulung , Teori-Teori Kesehatan Mental, Jakarta: Al-Husna Zikra, 1996

J.j Monks, Psiklogi Perkembangan, Terjemahan Siti Rahayu, Yokjakarta: Gajah Mada University Pers, 1982

Muhammad Ali, Muhammad asrori, Psikologi Remaja, Jakarta: Bumi Aksara, 2004.

Monzer Khaf, Ekonomi Islam, Yokyakarta : Pustaka Pelajar,1985.

Schoib Hawari, Pola Asuh Orangtua, http.www.com, diakses 25-3-2015 pukul 20.00WIB.

Strawaji, Kesehatan Mental, http.www.com, diakses 30-3-2015, pukul 20.00 Wib.

Syamsul Yusuf, Psikologi Belajar Agama, Persfektif Agama Islam, Bandung: Pustaka Bani Quraisy, 2005

Zakiah Drajat, Kesehatan Mental, Jakarta: Kalam Mulia, 2001. 